\title{
The use of RAPD markers to detect genetic patterns in Aleurodicus dispersus (Hemiptera: Aleyrodidae) populations from the Canary Islands
}

\author{
Carmen CALleJaS ${ }^{1}$, Francisco J. BeITIA ${ }^{3}$, Antonio GOBBI $^{2}$, Ana VELASCO $^{1}$ and M. Dolores OCHANDO $^{1 *}$ \\ ${ }^{1}$ Departamento de Genética, Facultad de CC. Biológicas, Universidad Complutense, Ciudad Universitaria, 28040 Madrid, Spain \\ ${ }^{2}$ Instituto Nacional de Investigación y Tecnología Agraria y Alimentaria (INIA), Apartado Oficial, 28080 Madrid, Spain \\ ${ }^{3}$ Instituto Valenciano de Investigaciones Agrarias (IVIA), Apartado Oficial, 46113 Moncada (Valencia), Spain
}

Key words. Aleurodicus dispersus, spiralling whitefly, RAPD-PCR, genetic variability, colonization

\begin{abstract}
Aleurodicus dispersus Russell (Hemiptera: Aleyrodidae), a highly polyphagous species, has since the 90's been an important pest of ornamentals and tropical crops in the Canary Islands. In this study the RAPD-PCR technique was used to study the genetic structure of this whitefly in this archipelago. A total of 68 different bands were scored in seven populations using six primers for amplification. No differences in RAPD patterns were found among populations from different islands of the Canaries. These findings indicate a very high genetic similarity among populations and low level of genetic variability and support a single colonization event by few $A$. dispersus whiteflies and recent dispersion throughout the archipelago.
\end{abstract}

\section{INTRODUCTION}

The spiralling whitefly, Aleurodicus dispersus Russell 1965 (Hemiptera: Aleyrodidae), is a highly polyphagous species, which has been recorded on 38 genera of plants belonging to 27 families and more than 100 species, including many vegetable, ornamental and fruit crops (Waterhouse \& Norris, 1989). This whitefly, native to the Caribbean region, was first recorded in the Canary Islands in 1965 on Schinus terebinthifolius. Since then, the species has spread throughout the archipelago (Hernández et al., 1997; Beitia, 1998; Martin et al., 2000) and since the 90's has become an important pest of ornamentals and tropical crops. However, the colonization process and geographic source of the original population remain unknown.

One of the molecular techniques based on the Polymerase Chain Reaction (PCR), the RAPD-PCR (Random Amplified Polymorphic DNA), is being widely used in applied entomology (see Harry et al., 1998 for a review). Much work has been done on the sweetpotato whitefly, Bemisia tabaci (Gennadius), including genetic studies, but very little on $A$. dispersus. Despite its economic importance, little is known about the level and patterns of genetic variability in populations of the spiralling whitefly. Thus, in this work the RAPD-PCR technique was used to obtain information on the genetic variability of $A$. dispersus populations from the Canary Islands.

\section{MATERIAL AND METHODS}

Seven populations of $A$. dispersus from different islands of the Canaries and different hosts were surveyed (Table 1, Fig. 1). Whiteflies were preserved in $90 \%$ ethanol until DNA extraction. 50 adults from each population were analyzed. Moreover, 14 pupae from Costa Rica were used as an outgroup.

Genomic DNA was extracted as previously described by Higuchi (1989), with minor modifications. Individual whiteflies were crushed with a pipette tip in $0.5 \mathrm{ml}$ Eppendorf tubes containing $50 \mu$ of lysis buffer [PCR Stoffel Fragment buffer 10× (Applied Biosystems, Foster City, CA, USA), $1.5 \mathrm{mM}$ of $\mathrm{MgCl}_{2}, 3 \mu \mathrm{g}$ of proteinase $\mathrm{K}$ and $0.5 \mu \mathrm{l}$ of Tween 20]. The homogenate was incubated at $60^{\circ} \mathrm{C}$ for $60 \mathrm{~min}$ and then boiled at $95^{\circ} \mathrm{C}$ for $10 \mathrm{~min}$ to inactivate proteinase $\mathrm{K}$. Extracted DNA was stored at $-20^{\circ} \mathrm{C}$ until required.

Six different primers (Operon Tech., Alameda, CA, USA) were used for amplification (A03, A13, B08, C08, F06 and

TABLE 1. Aleurodicus dispersus samples of seven populations from the Canary Islands and one from Costa Rica, which were used in this study. In the fifth column the numbers indicate sampling localities as shown in Fig. 1.

\begin{tabular}{|c|c|c|c|c|}
\hline Code & Origin & Host & Collected & SL \\
\hline FUE & Corralejo, Fuerteventura & Strelitzia nicolai & 1996 & 1 \\
\hline GOM & Parador, La Gomera & Persea americana & 1998 & 2 \\
\hline GCR & San Agustín, Gran Canaria & Coccoloba uvifera & 1996 & 3 \\
\hline LAN & Fariones, Lanzarote & Schinus terebinthifolius & 1996 & 4 \\
\hline TEN-A & Punta Hidalgo, Tenerife & Cocos nucifera & 1998 & 5 \\
\hline TEN-B & Puerto de la Cruz,Tenerife & Musa acuminata & 1998 & 6 \\
\hline ICI & Insectario ICIA, Tenerife & Psidium guajava & 1998 & \\
\hline CTR & Provincia Limón, Costa Rica & Musa sp. & 1999 & \\
\hline
\end{tabular}

\footnotetext{
* Corresponding author; e-mail: dochando@bio.ucm.es
} 


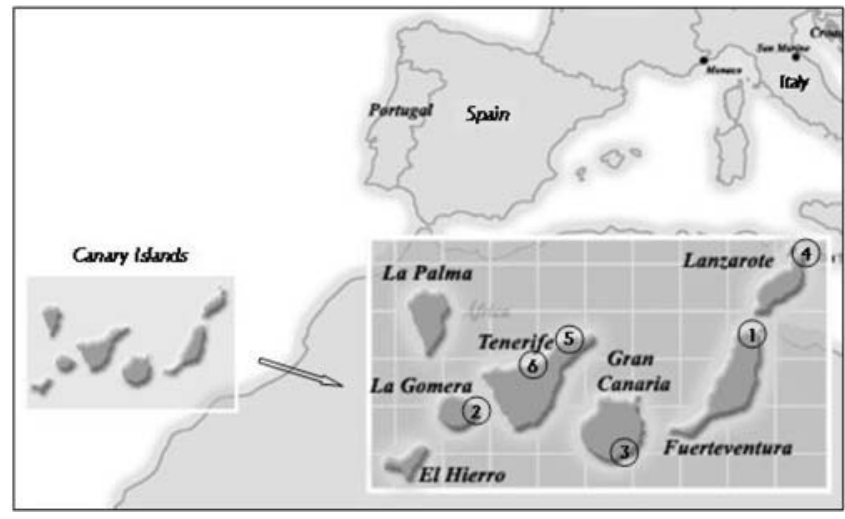

Fig. 1. Map showing the location of 6 of the whitefly populations sampled in this study.

F08). Reactions were performed in a volume of $12.5 \mu 1$ containing PCR Stoffel Fragment buffer 10× (Applied Biosystems), $4 \mathrm{mM} \mathrm{MgCl}, 0.2 \mathrm{mM}$ of each dNTP, 2.5 pmoles of primer, 0.8 $\mathrm{U}$ of Stoffel Fragment DNA polymerase and $2.0 \mu \mathrm{l}$ of the extracted DNA. The programme was: $94^{\circ} \mathrm{C}$ for $5 \mathrm{~min}, 45$ cycles of amplification $\left(1 \mathrm{~min}\right.$ at $94^{\circ} \mathrm{C}, 1 \mathrm{~min}$ at $36^{\circ} \mathrm{C}, 6 \mathrm{~min}$ at $72^{\circ} \mathrm{C}$ ) and a final step of $6 \mathrm{~min}$ at $72^{\circ} \mathrm{C}$. The amplification products were loaded onto $2.0 \%$ agarose gels in a buffer solution (1× TAE) containing ethidium bromide $(0.5 \mu \mathrm{g} / \mathrm{ml})$. A molecular weight marker (100 bp Ladder Plus, MBI Fermentas, St. LeonRot, Germany) was used as a standard.

Reactions were performed in a laboratory under standard conditions following the described protocol and with, at least, two replicates for each amplification reaction. Each individual was scored for presence (1) or absence (0) of every amplification product and a binary matrix was produced.

\section{RESULTS AND DISCUSSION}

All the amplification products obtained were reproducible and consistent. Fig. 2 shows an example of the RAPD profiles obtained with primer C08. A total of 68 different bands were scored with the six primers used, ranging from 240 to $1400 \mathrm{bp}$ in size. The number of bands observed for each primer ranged from 7 to 22 (Table 2).

TABLE 2. RAPD bands obtained. First column: primers used. Second column: total number of bands. Third column: bands present in all whiteflies (CI: Canary Islands populations, CR: Costa Rican population). Fourth and fifth columns: bands present in one of the two sample groups, i.e. Canaries or Costa Rica. Sixth and seventh columns: polymorphic bands.

\begin{tabular}{lccccccc}
\hline Primer & \multicolumn{2}{c}{ Total no. Monomorphic } & \multicolumn{2}{c}{ Monomorphic } & \multicolumn{2}{c}{ Polymorphic } \\
& of bands & CI + CR & CI & CR & CI & CR \\
\hline A03 & 10 & 9 & 0 & 1 & 0 & 0 \\
A13 & 8 & 7 & 0 & 0 & 0 & 1 \\
B08 & 7 & 5 & 2 & 0 & 0 & 0 \\
C08 & 22 & 2 & 9 & 6 & 1 & 4 \\
F06 & 10 & 8 & 0 & 2 & 0 & 0 \\
F08 & 11 & 5 & 4 & 2 & 0 & 0 \\
TOTAL & 68 & 36 & 15 & 11 & 1 & 5 \\
\hline
\end{tabular}

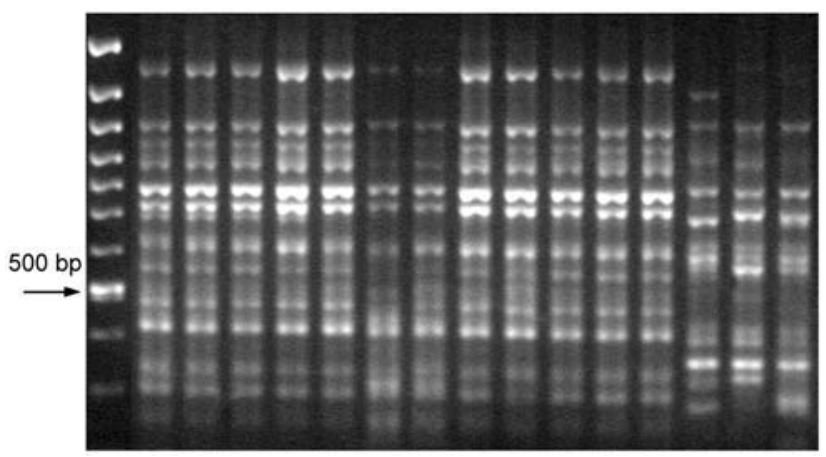

Fig. 2. RAPD profiles of the A. dispersus flies analyzed with primer $\mathrm{C} 08$. The first lane includes a $100 \mathrm{bp}$ ladder molecular weight marker and lanes 2-16 are for samples from the different populations (see Table 1): lanes 2-4: FUE; lanes 5 and 6: TEN-B; lanes 7 and 8: ICI; lanes 9 and 10: TEN-A; lanes 11-13: LAN; lanes: 14-16 CTR.

No differences in the RAPD patterns were found among the populations from the different islands of the Canary Islands. RAPD analysis revealed "regional" diagnostic bands, that is, bands of DNA present in all whiteflies from the Canary Islands but absent in those from Costa Rica (CTR) and vice versa (11 in the Costa Rican whiteflies and 15 in those from the Canary Islands). Primers C08 and F08 generated the majority of these diagnostic markers. Likewise, 5 DNA bands were polymorphic (variable) in Costa Rican samples but absent in those from the Canary Islands. All these bands indicate a clear differentiation between the two areas studied.

A. dispersus populations from the Canary Islands showed low levels of variability and general genetic similarity. As Mayr pointed out (1963), the population structure of a species after its introduction into a new geographic area is strongly governed by the founder effect. On the basis of the data obtained it would appear that since its introduction into the Canary Islands, the number of generations (9-12 according to data in HernándezSuarez, 1999) that have elapsed is insufficient to generate variability and/or the selection pressure on $A$. dispersus was insufficient to overcome the founder effect.

Probably all haplodiploid species have lower levels of genetic variability than bisexual species, in which both sexes are diploid and as a result all loci are exposed to selection in the hemizygous condition. Nonetheless, studies of sweet potato whitefly (B. tabaci) populations (Moya et al., 2001; Lima et al., 2002) as well as other haplodiploid insects show relatively high levels of genetic variability (i.e., Simon et al., 1999; Yvon \& Peros, 2003).

In contrast, our results show a high degree of genetic similarity among populations; this is consistent with the study of Shufran et al. (1997) on the Russian wheat aphid, Diuraphis noxia, another haplodiploid species (no genotypic differences were detected among the aphid clones ten years after its introduction into the United States). No genetic differences among the Canary Islands populations of $A$. dispersus were detected with the six primers used. There were no differences related to geographic origin, host-plant or year of collection. Therefore, based on our data, there is only one biotype of Aleurodicus dispersus in the Canary Islands.

In summary, as little genetic variability was detected and all populations from the Canary Islands shows the same DNA bands, it is likely that these Islands were colonized once by a few $A$. dispersus whiteflies, the offspring of which have recently dispersed throughout the archipelago. Given that this insect is a 
serious pest in the Canaries, this technique provide baseline information for monitoring the origin and spread of other insect pests. Nevertheless, other PCR methods need to be used in order to verify these findings.

ACKNOWLEDGEMENTS. Authors thank A. Carnero and E. Hernandez for their help in obtaining samples of whiteflies from the Canary Islands. This work was supported by the National Research Project: AGF97-1206-C02-02 (Spanish Ministry of Science and Technology).

\section{REFERENCES}

Beitia F. 1998: Nueva especie de mosca blanca en las Islas Canarias. Terralia 4: 24-25.

Harry M., Robin S. \& Lachaise D. 1998: L'utilisation de marqueurs génétiques polymorphes (RAPDs) en entomologie évolutive et appliquée. Ann. Entomol. Soc. Fr. 34: 9-32.

HernÁNDEz-SuÁrez E. 1999: La familia Aleyrodidae y sus enemigos naturales en las Islas Canarias. PhD Thesis, Universidad de La Laguna, Tenerife, Islas Canarias, $687 \mathrm{pp}$.

Hernández-Suárez E., Carnero A., Hernández M., Beitia F. \& Alonso C. 1997: Lecanoideus floccissimus (Homoptera, Aleyrodidae): Nueva plaga en las Islas Canarias. Phytoma (España) 91: 35-48.

HigUCHI R.G. 1989: Simple and rapid preparation of samples for PCR. In Erlich H.A. (ed.): PCR Technology. Stockton Press, New York, pp. 31-38.

Lima L.H.C., Campos L., Moretzsohn M.C., Navia D. \& DE Oliveira M.R.V. 2002: Genetic diversity of Bemisia tabaci (Genn.) populations in Brazil revealed by RAPD markers. Genet. Mol. Biol. 25: 217-223.
Martin J.H., Mifsud D. \& Rapisarda C. 2000: The whiteflies (Hemiptera: Aleyrodidae) of Europe and the Mediterranean Basin. Bull. Entomol. Res. 90: 407-448.

MAYr E. 1963: Animal Species and Evolution. Harvard University Press, Cambridge, MA, 797 pp.

Moya A., Guirao P., Cifuentes D., Beitia F. \& Cenis J.L. 2001: Genetic diversity of Iberian populations of Bemisia tabaci (Hemiptera: Aleyrodidae) based on random amplified polymorphic DNA-polymerase chain reaction. Mol. Ecol. 10: 891-897.

Russell L.M. 1965: A new species of Aleurodicus Douglas and two close relatives (Homoptera, Aleyrodidae). Fla. Entomol. 48: 47-55.

Simon J.C., Baumann S., Sunnucks P., Hebert P.D.N., Pierre J.S., Le-Gallic J.F. \& Dedryver C.A. 1999: Reproductive mode and population genetic structure of the cereal aphid Sitobion avenae studied using phenotypic and microsatellite markers. Mol. Ecol. 8: 531-545.

Shufran K.A., Burd J.D. \& Webster J.A. 1997: Biotypic status of Russian wheat aphid (Homoptera: aphididae) populations in the United States. J. Econ. Entomol. 90: 1684-1689.

Waterhouse D.J. \& Norris K.R. 1989: Aleurodicus dispersus spiralling whitefly. In: Biological Control Pacific Prospects Supplement 1. Australian Center for International Agriculture Research, Canberra, Australia, pp. 12-23.

Yvon M. \& Peros J.P. 2003: Variation in aggressiveness and genetic diversity of grape phylloxera in southern France. $J$. Int. Sci. Vigne Vin 37: 77-84.

Received October 15, 2004; revised and accepted December 14, 2004 